\title{
THE EXCURSION
}

\author{
Ruby Todd
}

It was years before I realised the impact of the trip to the Rock on my life. In my thoughts I come upon it again and again, like a dreamer in their labyrinth of images who thinks they have embarked on a journey, only to find themselves verging on a landscape they had never left.

The facts are well-known. Mamelon: spoken like an incantation by the otherwise practical Ms. Clarke, the Geography teacher, at the helm of the bus, as the last head was counted and we lurched out the gates, twenty-seven wideeyed girls in hats, nursing lunch bags heralding our names. It was the last excursion for the year, an unblinking day in December, blue-skied and hot.

'A mamelon is a rare geological formation, an extinct volcano,' said Ms. Clarke, holding onto the rails as we rounded a bend, the dry caw of her voice quickened with wonder. 'Millions of years ago, when this volcano erupted, the magma cooled around its mouth instead of flowing out. Through the ages, from the effects of wind and rain and ice, this lava was fractured and sloughed away and shaped to form the object of our visit today: Hanging Rock.'

From my window seat, I watched the school recede. I hadn't wanted to go that day. While I was fervently curious to see the Rock, I did not want to see it by way of yet another school excursion, herded and prodded and made to attend to the pedagogical agenda of whichever enterprising teacher had organised it.

Some of the girls behind me spoke of Miranda and the other lost girls, as if they too might be lost to the mysterious forces of the Rock that very afternoon. I imagined a less exciting scenario. But then, it seemed that I was the only one who had read Joan Lindsay's book. My classmates rolled their 
eyes when I turned to tell them that Picnic at Hanging Rock was almost certainly a fiction. That, after all, was a notion many refused to believe, and part of what had made the tale legendary. For my classmates, the prospect of being lost on the Rock was more thrilling than a geography lesson, and with that I couldn't disagree.

Turning from the girls behind me, I noticed Marie, the student-teacher from England. With her long dark hair and graceful reserve, she impressed me as a figure from another time. I assumed that she, at least, had read the book, and was of a similar opinion. Marie had been sitting in on our class for two weeks, assisting with Geography and English, and I supposed that like the student-teachers before her, she would soon be gone. I recalled the afternoon when she approached me while on yard duty. I was on the bench beneath the willow, my attention caught between the trials of Moll Flanders and the comings and goings of people and cars in the sunlit street beyond the gates, which with its kept lawns and laceworked Victorians, had a look of false innocence. Marie leaned against the willow and smiled, as if she could see something that I could not. It was a smile of frankness alien to my experience of teachers, a smile that reached beyond the afternoon lunch hour in which it occurred.

'I haven't read that one,' she said, gesturing toward the book. 'How is it?'

'Well,' I said after a while, 'I can see how one bad decision made early can lead to many worse ones. Especially for someone who didn't have a great start in life.'

Marie nodded, and for a moment we looked out to the street, where an older woman in pressed slacks and frosted lipstick was walking with purpose, carrying bags of shopping, as a fat Jack Russell lagged behind.

'You know, it won't always be like this,' Marie said eventually. 'One day it will be over and you'll be free. But the strength you'll have then is a strength you have already. Because you're not afraid of being alone.'

She glanced at me sidelong, took a deep breath and shrugged her shoulders as if at the unalterable order of things. 'Happy reading,' she said finally, moving away before I could respond.

The way that Marie had looked at me and the way she had spoken told me that those words were not like the words I had heard from other adults-dry, 
glassy words cast off to placate me. Instead, she had given me the gift of hindsight from a future self, who had known the wastelands of adolescence and survived. I carried those words in my mind for years.

Despite the heat at the Rock that day, it was windy. I remember the feeling of my school dress fluttering against my legs and thinking of how cumbersome dresses must have been at the turn of the century on a bushwalk, designed to buffer the body from the sensuous pleasures of nature and the elements. When we stepped from the bus onto the hot gravel of the car park, the wind blew summer hats off several heads, and caused Ms. Clarke to claw hair from her eyes and frown as we chased them, skittering beyond us in the shadow of the Rock. When I had caught my hat, I looked up and saw it, looming on the mountain like an apparition of an age before man, aflame in the sun. I could imagine why young Joan Lindsay, having seen it a century ago on a trip by buggy with her own Clyde Girl's School, might have felt it linger in her mind. And yet I could also see how many others, less alive perhaps to imagined possibilities, could simply have seen it, agreed that it was quite a singular formation, and thought little of it upon leaving.

When we were all counted and lined up two-by-two, Ms. Clarke appealed to our sense of history. 'Well, girls, the Rock!' she declared with a grin, sweeping her arm behind her. 'Just think of it-this rock is older than civilisation, older than humanity itself! In comparison to it, Ancient Greece was modern, and the cave paintings of Lascaux made yesterday! The earth works on a different scale of time to our own. To the rock, this century will have been the blink of an eye. When we walk around today, I'd like you to keep that in mind. I'd like you to think of all the Rock has seen, and all the people who have visited before us, in very different times to our own.'

Having always enjoyed the anachronistic and vertiginous sense of experiencing myself in a place where those from other ages had gone before me, I did as I was told, and remember feeling stupefied and unequal to the challenge. As we walked up the path that wound around the base of the rock to 
its summit, we were encouraged to look for various colourfully-named notable formations which were depicted on the educational sheets we were given. We marked them on a corresponding map: the Saddle, the Chapel, the Black Hole of Calcutta. The effect was to reduce our experience of the rock to filling in blanks and copying from each other until the task was done. I sensed this early on, and abandoned my efforts, loitering behind the others as they looked for the next landmark.

When I heard the cry, I was in the shadow of a cave, inspecting a colony of ants carrying the crumbs of an abandoned sandwich across minute canyons in the red earth. I had wondered where they were travelling to, and as one lost its way at the base of my shoe, I experienced a transformation of perspective: my own familiar feet, in brown lace-ups, were of a giant. My mind had summoned a passage from Lindsay's book: Everything if you could only see it clearly enough, is beautiful and complete.

The cry was a sound wrenched from the body of its owner, which as soon as it sounded caused a quavering of voices from all around. Except mine, because for a time, as if the violent commotion around me was beyond a great wall of glass, my gaze remained on the ants. As I watched them, everything else seemed to darken and close in. I knew something terrible had happened. Somehow, I was not surprised.

I don't recall how long it was before I finally arrived, some metres away at the edge of the path, where everyone had clustered like the faithful for an address. It was only when I moved closer that I saw the great fallen gum, and two feet sticking out, in the jelly sandals that were popular then. It was Marie's body that the gum had pinned, on a diagonal axis from neck to hip. I looked for Ms. Clarke and supposed she had gone down for help. Like a wave, sobs began to break from the girls. I scrambled through them, and kneeled in the dirt before Marie, who fixed her enormous eyes on me, her face wincing and white. Without knowing what to do, I took her hand and told her to squeeze. 'Help will be here soon, Marie,' I said. 
She couldn't move her neck, and was straining to breathe. When she spoke, I had to lean in to hear her. 'I'm so far from home,' she said.

I pressed my free hand to her cheek and stared. A moment later the pressure from her hand weakened, and she didn't respond to my voice. Inert, as a kookaburra called overhead and I felt everything in my vision lose its distinction, I kept my gaze on her open eyes, in which I could dimly see my own reflection.

As I heard the urgent voices of adults approaching from the path, a sentence from the book crept over me like something alive: Everything begins and ends in exactly the right time and place.

Its prim absurdity made me want to scream.

\section{Source note:}

Italicised passages on pages 4 and 5 are quotations from pages 35 and 121 respectively, of Joan Lindsay's classic 1967 novel, Picnic at Hanging Rock (1998 Vintage edition). 